\title{
The influence of wetting and drying paths on the shear strength of a silty clayey compacted soil
}

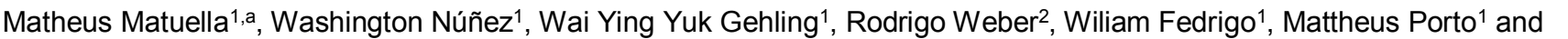

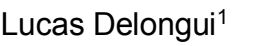

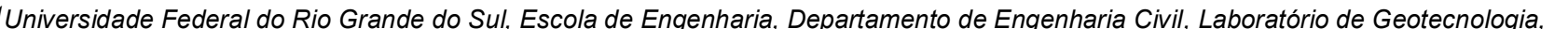

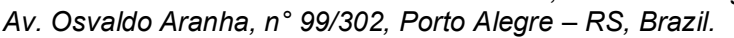

प

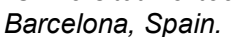

\begin{abstract}
The vast majority of geotechnical projects are designed in saturated condition, aiming safety. However, when some conditions might be achieved, designing in unsaturated conditions may end up being economically interesting, while still safe. Therefore, this study aims at evaluating the shear strength behaviour of a silty clayey soil, with optimum moisture content of $16 \%$ and dry unit weight of $16,5 \mathrm{kN} / \mathrm{m}^{3}$ from south Brazil. From direct shear tests, performed in saturate and unsaturated conditions, with three different starting moisture conditions $-14 \%, 16 \%$ and $18 \%$, and the same unit weight, this paper shows the influence of the wetting and drying paths on this material and its contribution to evaluate shear strength. The results showed that a variation of $\pm 2 \%$ around the optimum, in drying and wetting paths, can significantly influence the behaviour of the studied material. The wetting process caused a small variation in comparison with the optimum, while the drying process resulted in increased shear resistance for all the analyzed samples. With this study, it was possible to obtain a better understanding of the behaviour of an unsaturated soil from south Brazil, when evaluating tradeoffs in project's safety and economics.
\end{abstract}

\section{Introduction}

The layers that form a pavement structure are compacted at optimum moisture content $(\omega)$, therefore in unsaturated conditions. These layers' moisture content (and of the subgrade) may vary during the construction of a pavement, due to poor technical control or even deliberate not following standardization. It's known that the characteristics of the soil where the pavement is settled directly influence its lifetime; following Brazilian standardization DNIT 137/2010 [1], there is a tolerance of $\pm 2 \%$ around optimum moisture content $\left(\omega_{0}\right)$. Even though the moisture content may be altered during construction and also after the structure is opened to traffic, seasonal weather conditions may also influence the saturation level, compromising the pavement's performance.

Considering the importance of saturation conditions of the soils when building these structures, the evaluation of the shear strength - tied up to the moisture content at time of compaction, and also to wetting and drying paths, induced by climate conditions - may influence significantly pavements analysis and design. Several papers highlight the importance of evaluating pavements' mechanical behaviour and the relevance of knowing the materials' properties, such as Rodrigues (1997, [2]),
Zaman and Khoury (2007, [3]), Chittoori et al. (2012, [4]), Weber (2013, [5]) and Matuella et al. (2014, [6]). By this mean, the present study aims at evaluating the shear strength of a soil against variations in the moisture content after its compaction.

\section{Material and methods}

The experimental program consisted in two main steps: the first was to choose the soil to be analyzed, based on its applicability as a pavement material; the second was to arrange test procedures that would make possible to evaluate moisture content variations during and after compaction and its influence in the soil shear strength. It is assumed that those variations might be related to climate changes and to possible construction problems, which could be reproduced in laboratory by wetting and drying paths.

\subsection{Material of study}

The studied soil was collected in the Brazilian highway BR-116, near the city of Porto Alegre, located in the state of Rio Grande do Sul. Figure 1 shows the location where the studied soil has been collected from. This soil was

\footnotetext{
a Corresponding author: m.matuella@gmail.com
} 


\section{E-UNSAT 2016}

chosen because it was part of a quarry that would be used in the highway's duplication. Some characteristics of the studied soil are presented in Table 1. Figure 2 shows the compaction curve obtained for the studied soil while Figure 3 presents its grain size distribution curve. The soil specimens were compacted using standard Proctor effort and then shaped in order to carry out direct shear tests and suction tests.

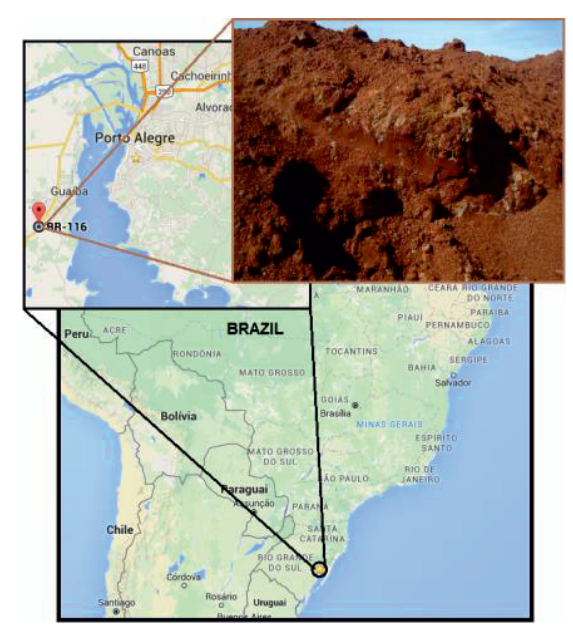

Figure 1. Location where the soil was collected from.

Table 1. Soil physical properties.

\begin{tabular}{|c|c|c|c|c|}
\hline \multirow{2}{*}{$\begin{array}{c}\text { Grain size } \\
\text { distribution }\end{array}$} & Size & $\begin{array}{c}\text { San } \\
\mathrm{d}\end{array}$ & Silt & Clay \\
\cline { 2 - 5 } & $\begin{array}{c}\text { Without } \\
\text { dispersant }\end{array}$ & $31 \%$ & $65 \%$ & $4 \%$ \\
\hline $\begin{array}{c}\text { Compaction } \\
\text { test results } \\
\text { (Standard } \\
\text { Proctor) }\end{array}$ & $\omega_{0}$ & \multicolumn{2}{|c|}{$16 \%$} \\
\cline { 2 - 5 } & $\gamma_{\mathrm{d}}$ & \multicolumn{2}{|c|}{$16,5 \mathrm{kN} / \mathrm{m}^{3}$} \\
\hline \multirow{2}{*}{$\begin{array}{c}\text { Atterberg } \\
\text { Limits }\end{array}$} & Llaquid limit & \multicolumn{2}{|c|}{$36 \%$} \\
\cline { 2 - 5 } & Plasticity index & \multicolumn{3}{|c|}{$27 \%$} \\
\hline
\end{tabular}

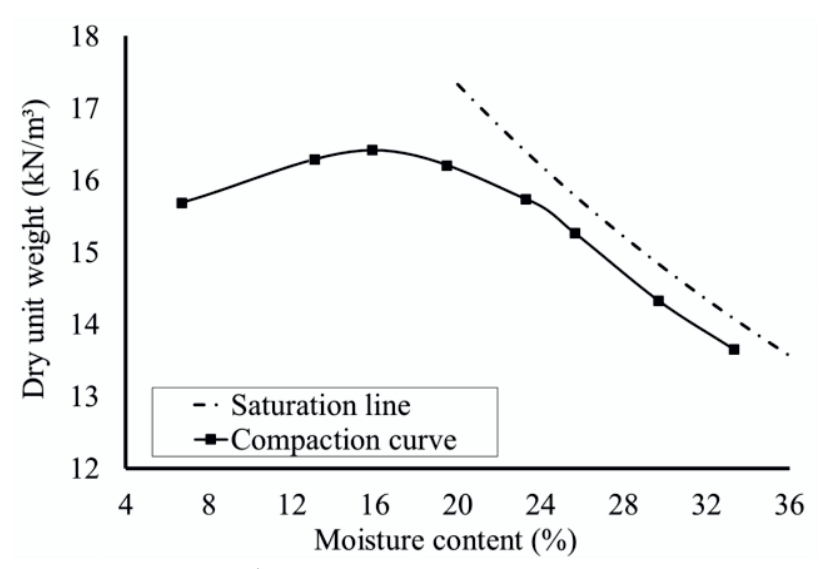

Figure 2. Compaction curve.

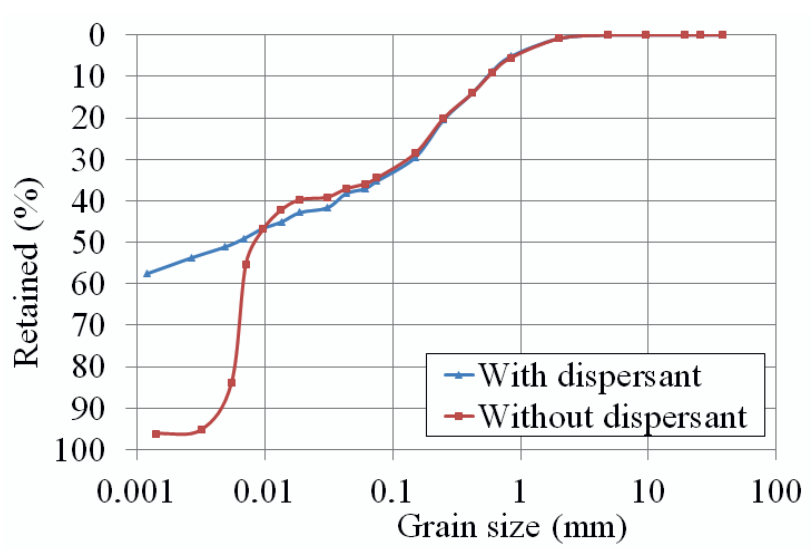

Figure 3. Grain size distribution curve.

\subsection{Direct Shear Test}

The direct shear test was adopted because of two main reasons: relatively fast results and simple testing procedures, following ASTM D3080 [7].

Cylindrical specimens with $6 \mathrm{~cm}$ in diameter and 2 $\mathrm{cm}$ in height were compacted with moisture contents equal to $14 \%, 16 \%$ and $18 \%$ (within the allowable limits established by DNIT 137/2010). Some samples were then wet, some of them dried and some of them remained at the same moisture content. The specimens in the drying path were air dried and water was added to the specimens in the wetting path. In both cases, the moisture content was controlled by mass variation; after achieving the correct content, the specimens were wrapped in plastic film and stored in order to provide homogeneity in moisture. Table 2 synthesizes the moisture content at compaction and while the tests were run.

Table 2. Variations of the friction angle as function of the moisture content at compaction and wetting/drying paths.

\begin{tabular}{|c|c|c|}
\hline Path & $\begin{array}{c}\boldsymbol{\omega} \text { at } \\
\text { compaction }\end{array}$ & $\begin{array}{c}\boldsymbol{\omega} \text { at } \\
\text { testing }\end{array}$ \\
\hline \multirow{4}{*}{ No path } & 14 & saturated \\
\cline { 2 - 3 } & 16 & saturated \\
\cline { 2 - 3 } & 18 & saturated \\
\cline { 2 - 3 } & 14 & 14 \\
\cline { 2 - 3 } & 16 & 16 \\
\hline \multirow{3}{*}{ Wetting } & 18 & 18 \\
\cline { 2 - 3 } & 14 & 16 \\
\hline \multirow{3}{*}{ Drying } & 16 & 18 \\
\cline { 2 - 3 } & 18 & 20 \\
\cline { 2 - 3 } & 16 & 12 \\
\hline
\end{tabular}

When tested under saturated conditions, the soil specimens were compacted at desired moisture content, placed at the Wykeham Farrance equipment for direct shear test, shown in figure 4 , where they were flooded, thickened up to stabilization, and then tested. 


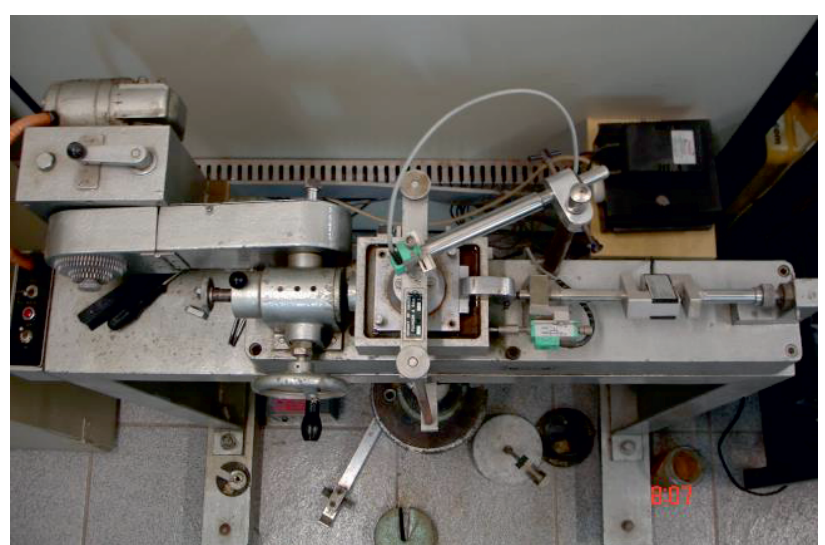

Figure 4. Wykeham Farrance equipment for direct shear test.

During the test, it was observed that the moisture content was constant in the unsaturated condition. On the other hand, the saturated condition tests were carried out after keeping the specimens in water during a predefined period of time in order to achieve complete saturation. The applied normal stresses were $25 \mathrm{kPa}, 50 \mathrm{kPa}$ and 100 $\mathrm{kPa}$ and two hypotheses were assumed as rupture criteria: the shear stress stabilization or a horizontal displacement of $10 \%$ the specimen diameter.

\section{Results and analysis}

From the stress $\mathrm{x}$ strain curves obtained at the direct shear test to the set of conditions studied, the following shear stress $(\mathrm{T}) \mathrm{x}$ normal stress $(\sigma)$ graphics, shown in Figures 5 to 8 , were plotted.

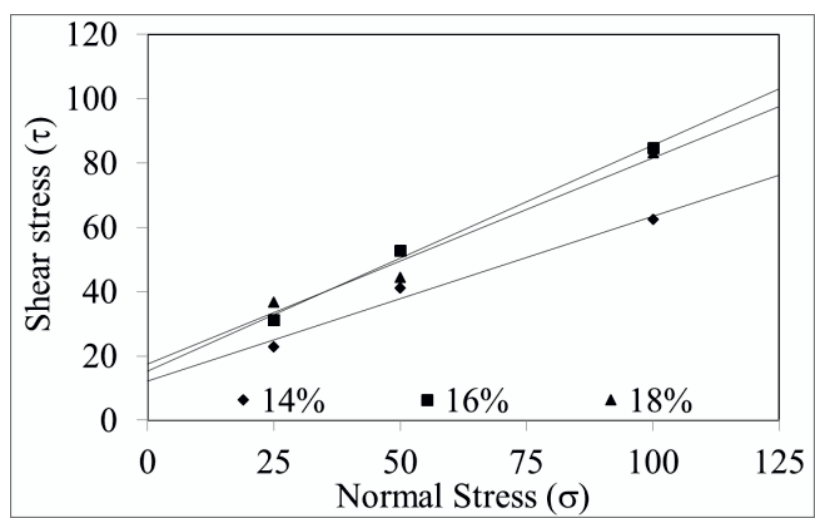

Figure 5. . T $x \sigma$ diagram for saturated samples.

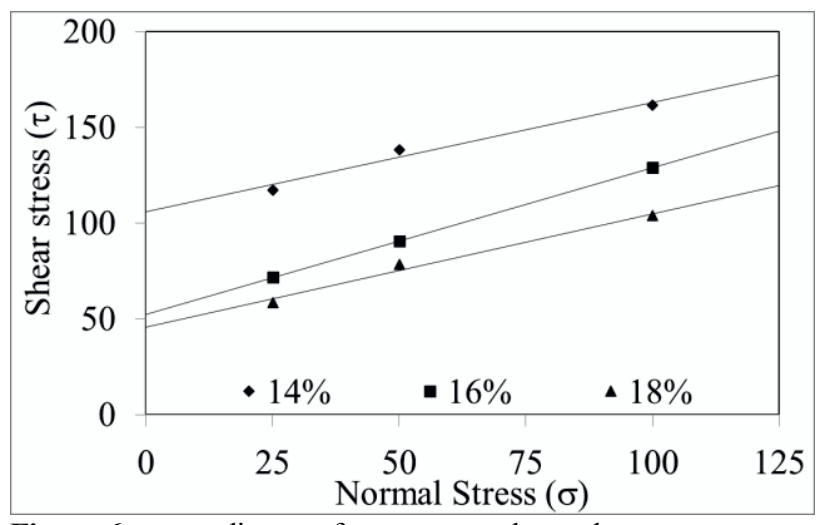

Figure 6. . T $x \sigma$ diagram for unsaturated samples.

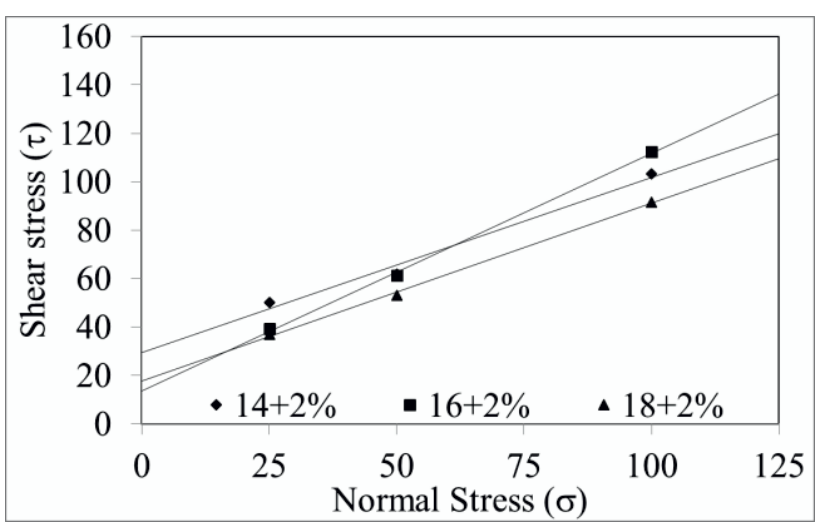

Figure 7. . T $x \sigma$ diagram for unsaturated samples under a wetting path.

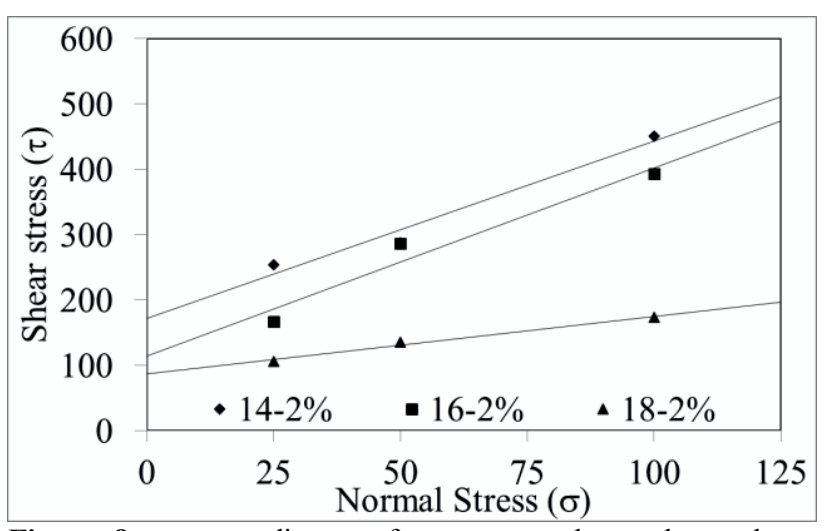

Figure 8. . T $x \sigma$ diagram for unsaturated samples under a drying path.

The results were then summarized; table 3 shows the variation of the friction angle, while table 4 expresses the variations in the cohesion, both related to moisture content of the samples at the moment they were tested.

Table 3. Variations of the friction angle, related to the moisture content at compaction and wetting/drying paths.

\begin{tabular}{|c|c|c|c|c|}
\hline \multirow{2}{*}{$\begin{array}{c}\boldsymbol{\omega} \text { at } \\
\text { compact- } \\
\text { tion }\end{array}$} & \multicolumn{4}{|c|}{ friction angle $\left.-\boldsymbol{\phi} \mathbf{(}^{\mathbf{}}\right)$} \\
\cline { 2 - 5 } & $\begin{array}{c}\text { Satu- } \\
\text { rated }\end{array}$ & $\begin{array}{c}\text { Unsa- } \\
\text { turated }\end{array}$ & $\begin{array}{c}\text { Wet } \\
(+2 \%)\end{array}$ & $\begin{array}{c}\text { Dried } \\
(-2 \%)\end{array}$ \\
\hline $14 \%$ & 27,1 & 29,7 & 35,8 & 69,8 \\
\hline $16 \%$ & 35,1 & 37,4 & 44,5 & 70,9 \\
\hline $18 \%$ & 32,6 & 30,5 & 36,3 & 41,4 \\
\hline
\end{tabular}

Table 4. Variations of the cohesion as function of the moisture content at compaction and wetting/drying paths.

\begin{tabular}{|c|c|c|c|c|}
\hline \multirow{2}{*}{$\begin{array}{c}\omega \text { at } \\
\text { compact- } \\
\text { tion }\end{array}$} & \multicolumn{4}{|c|}{ Cohesion (kPa) } \\
\cline { 2 - 5 } & $\begin{array}{c}\text { Satu- } \\
\text { rated }\end{array}$ & $\begin{array}{c}\text { Unsa- } \\
\text { turated }\end{array}$ & $\begin{array}{c}\text { Wet } \\
(+2 \%)\end{array}$ & $\begin{array}{c}\text { Dried } \\
(-2 \%)\end{array}$ \\
\hline $14 \%$ & 12,2 & 105,8 & 29,6 & 172,0 \\
\hline $16 \%$ & 15,3 & 52,5 & 13,8 & 113,7 \\
\hline $18 \%$ & 17,5 & 45,8 & 17,8 & 86,8 \\
\hline
\end{tabular}

After obtained, these values were plotted in order to help in the analysis of the soil's mechanical behaviour. In figure 9, the variation of the cohesion is presented, 
related to the variations of moisture contents, while figure 10 shows the friction angle as function of the moisture content.

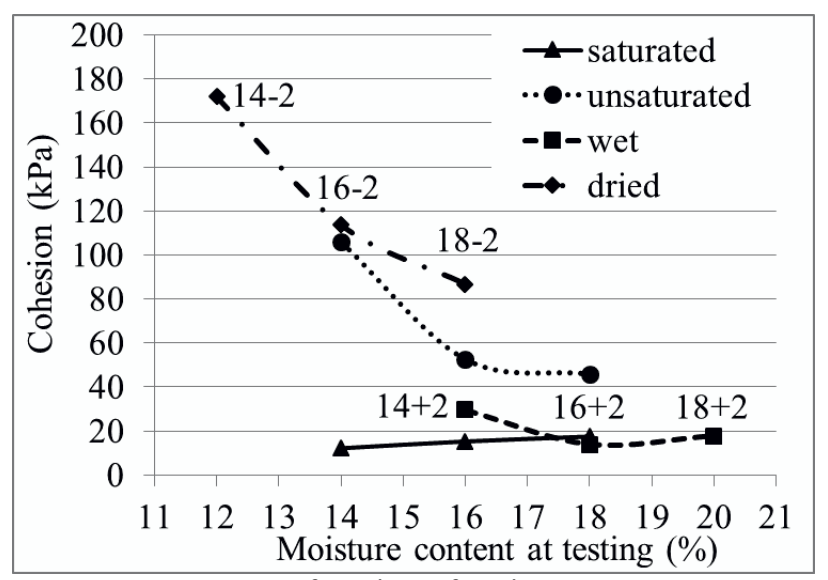

Figure 9. Cohesion as function of moisture content.

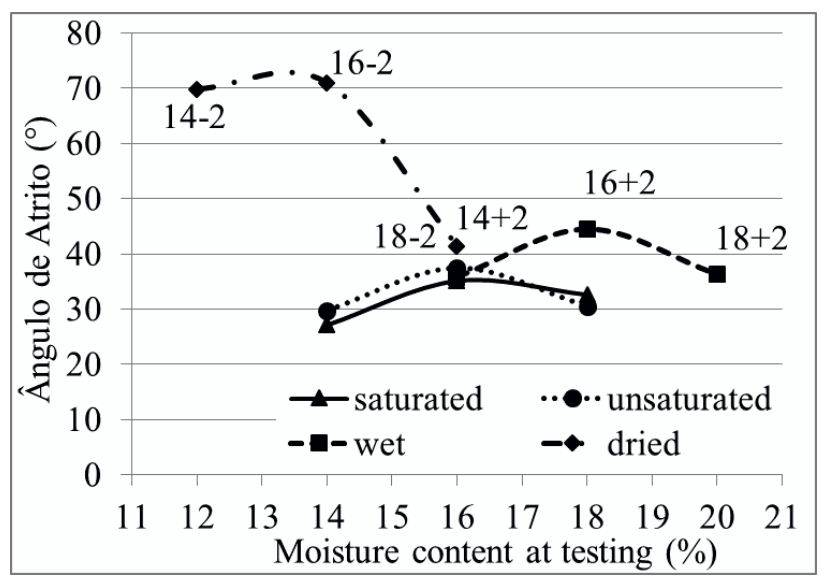

Figure 10. Friction angle as function of moisture content.

About the mechanical behaviour of this soil, as most relevant, it was observed that:

- Under saturated and under unsaturated conditions, the friction angle tends to have a maximum value, related to optimum moisture content at compaction. When under wetting paths, the samples compacted at optimum moisture content presented higher friction angle, compared to those which did not have its moisture changed. When not compacted at $\omega_{0}$, values of the same order of magnitude were obtained, as the ones resulted when the samples were tested at $\omega_{0}$, with no moisture variations. When analysing the samples that underwent the drying process, all the three cases showed an increase in the friction angle. In this case, the ones compacted at $14 \%$ and $16 \%$ presented exceedingly high values for this parameter. There is still lack of results to evaluate the behaviour of the drying paths, at lower moisture contents, to determine if the friction angles will stabilize, decrease or still show a peak value.

- The soil's cohesion, under saturated condition, presents a slight increment, as the moisture content at compaction increases, but this increment is not as notable as the cohesion obtained in unsaturated conditions. When compared directly, for every value of moisture content at compaction, cohesion under unsaturated conditions are roughly at least 3 times higher. As expected, the wetting path proved to be a worse condition when compared to all unsaturated samples. It was observed that the drying paths may endow the soil substantial improvements, in terms of cohesion (46 kPa to $87 \mathrm{kPa}$, for samples compacted at $18 \%, 52 \mathrm{kPa}$ to $114 \mathrm{kPa}$, for the samples compacted at $16 \%$ and $105 \mathrm{kPa}$ to $172 \mathrm{kPa}$, for those compacted at $14 \%$ of moisture content).

\section{Conclusion}

The experiments developed in this work allowed the evaluation of the behaviour of the shear strength of a compacted soil at different moisture contents, which were conducted through wetting and drying paths.

It was noticed that when this soil is compacted near optimum moisture content and, after compaction, it suffer loss of moisture, we can achieve considerable increases in shear strength. When the effect is the opposite and the moisture content of the material increases after compaction, there may be great resistance loss, particularly when the material is compacted below optimum moisture content.

These observations are of great relevance to the practical applications of geotechnical engineering. With proper control of soil moisture, we might save financial resources and get benefits in terms of security.

We can, for example, in long-term construction work, plan a certain excavation or cutting a slope, which should be done in a drier season when the soil is possibly less humid and hence support higher shear stresses and remain stable on steeper slopes. Another example to be taken into account is the construction of a highway: if we manage to control the moisture of the pavement support layers by installing devices which lead the water out of the pavement structure, or by using layers which allow the percolation of the water in a way that it wouldn't accumulate within the structure, we prevent these layers from loosing strength due to high humidity.

\section{References}

1. $\square$ Departamento Nacional De Infraestrutura De Transporte, DNIT 137/2010. Pavimentação Regularização do subleito - Especificação de serviço. Rio de Janeiro. [2010]

2. $\square$ M. R. De Rodrigues, Influência da sucção no módulo de resiliência de solos típicos de subleito de pavimentos do Rio Grande do Sul, Dissertação de Mestrado, Programa de Pós-Graduação Engenharia Civil, Departamento de Engenharia Civil, Universidade Federal do Rio Grande do Sul, 106 p. [1997]

3. $\square$ N. N Khoury, M. Zaman, Environmental Effects on Durability of Aggregates Stabilized with Cementitious Materials. ASCE JMCE, Vol. 19 (1), pp. 1-8, [2007]

4. $\square$ A. J. Puppala, T. Manosuthkij, S. Nazarian, L. R. Hoyos, B. Chittoori, In Situ Matric Suction and Moisture Content Measurements in Expansive Clay 
During Seasonal Fluctuations. GTJ Vol. 35.1 [2012]: 1-9.

5. $\square$ R. C. Weber, Avaliação das trajetórias de umedecimento e secagem na deformabilidade elástica de solos compactos. Dissertação de Mestrado, Programa de Pós-Graduação Engenharia Civil, Departamento de Engenharia Civil, Universidade Federal do Rio Grande do Sul, 139 p. [2013]

6. M. F. Matuella, W. P. Núñez, W. Y. Y. Gehling, R. C. Weber, Avaliação dos efeitos do teor de umidade de compactação e variações de umedecimento e secagem na resistência ao cisalhamento de um solo argilo-siltoso. In: Congresso Brasileiro de Mecânica dos Solos e Engenharia Geotécnica, 2014, Goiânia. COBRAMSEG 2014, [2014].

7. $\square$ American Society For Testing And Materials, ASTM D3080. Standard Test Method for Direct Shear Test of Soils Under Consolidated Drained Conditions. USA, [1998]. 